\title{
Cytoplasmic Tubular Aggregates and Nuclear Filamentous Bodies in Two Suspected Cases of Viral Encephalitis
}

\author{
DIKRAN S. HOROUPIAN, R. T. ROSS, MARK J. GURWITH, JAN HOOGSTRATEN
}

SUMMARY Two suspected cases of viral encephalitis are presented. Viral nucleocapsids were not seen, but cytoplasmic paramyxovirus-like aggregates and nuclear filamentous bodies were frequently encountered. Both structures were seen in the same cell. Contrary to other reports, the cytoplasmic aggregates were mostly observed in hematogenous mononuclear cells, less frequently in neuronal cell elements and rarely in endothelial cells. The nonspecific nature of these structures is emphasized.

RÉSUMÉ: Deux cas présumés d'encéphalite virale furent étudiés; aucune nucléocapside virale ne fut décélée, mais on dénombra beaucoup d'aggrégats cytoplasmiques, semblables à des paramixovirus, ainsi que des corps nucléaires filamenteux. Ceux-ci coexistaient dans la même cellule. Contrairement à d'autres rapports, la plupart des aggrégats cytoplasmiques furent découverts dans des cellules mononucléaires hématogènes, certains dans des éléments neuronaux, et très peu dans des cellules endothéliales. Le caractère non spécifique de ces structures est souligné.

From the Department of Pathology and Medicine Health Sciences Centre and Faculty of Medicine, University of Manitoba, Winnipeg, Canada.

Reprint address: Dr. D. S. Horoupian, Neuropathology Unit, Department of Pathology, Health Sciences Centre, 700 William Avenue, Winnipeg, Manitoba R3E 0Z3 Canada.

\section{INTRODUCTION}

Cytoplasmic paramyxovirus-like aggregates (Baringer and Swoveland, 1972) and whorled filamentous nuclear bodies ( $\mathrm{Zu}$ Rhein and Chou, 1968) have been frequently described in association with virus induced infectious and neoplastic conditions. To our knowledge, these two structures have not been described in the same patient, and the appearance of the former, at least in humans, has been usually confined to endothelial cells and less frequently to mononuclear cells (Baringer, 1971). This paper deals with two instances of suspected viral encephalitis in which these structures were present in the same biopsy material and the cytoplasmic aggregates were found in neuronal cell elements.

\section{CASE REPORT 1}

Miss M.A., a 16-year-old high school student, was admitted to hospital on September 17,1972 . Her family said that she had been unwell for one week and complained of paraesthesiae in her mouth, gums and teeth.

Two days before admission she complained of anorexia, vomited once and stopped eating entirely. She developed intermittent paraesthesiae of the right foot and arm which lasted for several minutes at a time and disappeared for several hours. She gradually became dysphasic, apprehensive and began to experience violent mood changes. Thirtysix hours prior to admission she had a nocturnal, generalized epileptic seizure. The next day her dysphasia was much worse, but she managed to make it known that she was experiencing constant right face, arm and leg paraesthesiae.
On admission, she was alert but had difficulty understanding commands. Her optic fundi, visual fields and cranial nerves were normal. She had bilateral flexor plantar responses. Her temperature was normal. Her chest, skull films, a left common carotid angiogram, and a brain scan were all normal.

Other investigations revealed a hemoglobin of $13.0 \mathrm{gms}$. \%, WBC 8900/cmm. with a normal differential and an erythrocyte sedimentation rate of $38 \mathrm{~mm}$. in one hour. Serum bilirubin, S.G.O.T., C.P.K. and alkaline phosphatase were all normal. Urinalysis, a Monospot test and indirect fluorescent antibody titers for toxoplasmosis were all negative. E.E.G. showed evidence of a severe disturbance of the left temporal lobe. Spinal fluid examination showed a glucose of $55 \mathrm{mgs} . \%$, protein 17 mgs. \%, 19 lymphocytes and 1 red cell $/ \mathrm{cmm}$. Cultures of C.S.F. for bacteria, fungi and mycobacteria were all negative.

On her third hospital day she underwent a left temporal lobe brain biopsy. On the basis of the pathology report it was decided to treat her as a suspect herpes simplex encephalitis with idoxuridine (IUDR) which was administered for five days, four grams per day. By the last day of therapy, her S.G.O.T. was 235, L.D.H. 220, and alkaline phosphatase 62 I.U. Her S.G.O.T. remained elevated for 50 days, although by the date of discharge it was normal. Her bilirubin rose to 1.8 mgs. \%.

On the ninth hospital day her level of consciousness was further depressed and lumbar puncture was repeated. Clear fluid under elevated pressure was removed containing $16 \mathrm{mgs}$. \% of protein and 20 lymphocytes per $\mathrm{cmm}$. All other constituents were normal.

Her subsequent hospital course was characterized by severe aspiration pneumonia, transient renal failure and a 
bleeding diathesis due to thrombocytopenia.

By October 24th, her mental status had improved. She could not speak or feed herself and was doubly incontinent. At times she had spontaneous violent rages. These were thought to be epileptic and were controlled with diphenylhydantoin and primidone therapy.

After two months stay in hospital she was discharged to a chronic disease hospital, completely aphasic and needing intensive nursing care. She returned home on the 30th of January, 1973, at which time she was capable of dressing and feeding herself and fully ambulatory. She was able to spell and write letters, read the newspaper, add, subtract, multiply and divide. Physical examination showed no abnormalities except for a speech stammer.

\section{CASE REPORT 2 - (C.W.)}

This 12-year-old Jamaican boy was admitted on the 14th of February, 1973 because of fever and a convulsion. The patient had lived in Canada for the last four years, but on the 23rd of December, 1972 he went to Jamaica for a vacation. While in Jamaica he had fever lasting for one day on the 5th and the 12th of January, 1973. He returned to Winnipeg on January 13th, 1973 and was treated with Synalar cream and clindamycin for "infected mosquito bites". On the 10th of February, 1973, he developed fever, chills, headache, vomiting and diarrhea and on the day of admission he was found on the floor unconscious.

His past history was unremarkable. There was no history of convulsive disorder, drug abuse or head injury.

At admission the patient responded only to pain and developed a generalized seizure while in the emergency room. There were no localizing neurological signs, although bilateral Babinski signs were present.

While in the hospital, the patient continued to have seizures, both generalized and focal, involving the right side. He remained febrile and finally required a tracheostomy. Laboratory findings included a hemoglobin of 11.2 gms. \%, a white cell count of $9,000 / \mathrm{cmm}$. with $67 \%$ granulocytes, $2 \%$ bands, $25 \%$ lymphocytes, $2 \%$ monocytes and $4 \%$ atypical lymphocytes. Platelets were normal. Urinalysis was normal. Chemical screening battery was normal with the exception of the C.P.K. of 4,790, L.D.H. of 285 , and S.G.O.T. of 148 I.U. Alkaline phosphatase and serum bilirubin were normal. Serum sodium was $141 \mathrm{mEq}$./L. A lum- bar puncture revealed clear colorless fluid with one white blood cell and 53 red cells. All cultures were negative. Protein was $25 \mathrm{mg}$. \% and sugar was $112 \mathrm{mg}$. \%. Subsequent spinal taps were essentially not altered. An echoencephalogram was normal. An E.E.G. was very abnormal, but with non-specific findings. A brain scan suggested increased activity in the right posterior fossa, but a right brachial angiogram showed no abnormalities. Chest X-ray and E.K.G. were normal.

On the 5th hospital day the patient underwent a right temporal lobe brain biopsy and was immediately started on IUDR. The IUDR was discontinued after two days when the pathological report on the brain biopsy was reported to be nondiagnostic. Routine cultures of the brain biopsy for fungi, mycobacteriae and viruses were negative.

The patient's subsequent hospital course was complicated by a left lower lobe pneumonia and a urinary tract infection and he remained febrile approximately $\mathbf{3 0}$ days.

On the 13th hospital day he began to respond to verbal commands and after one month he responded fully, and was able to repeat commands and walk. His neurological examination continued to show no focal abnormalities. L.D.H. and S.G.O.T. remained elevated throughout his stay in hospital. The last L.D.H. was 260 , but S.G.O.T. had fallen to $60 \mathrm{I} . \mathrm{U}$. His alkaline phosphatase rose to 215 while in hospital and when last measured was $175 \mathrm{I}$.U. Because of the persistent abnormal liver function, a liver biopsy was done which was considered to be normal.

Nine months later, the patient still suffers from local seizures and manifests serious behavioral difficulties.

\section{MATERIALS AND METHODS}

The brain biopsy was obtained from the left temporal lobe in case No. 1 and from the right side in case No. 2. The specimen was divided into four parts for: light microscopy, histochemistry, electron microscopy and virus studies.

For light microscopy, the formalin-fixed and paraffin-embedded tissue was stained with hematoxylin and eosin, luxol fast blue, phosphotungstic acid hematoxylin, and by the Bodian and Heidenhain techniques. For electron microscopy, $1 \mathrm{~mm}$. thick slices of grey and white matter were fixed in
$5 \%$ glutaraldehyde in phosphate buffer at $\mathrm{pH} 7.3$ and post fixed in buffered osmic acid for one hour. The tissues were washed with distilled water and put in $2 \%$ aqueous solution of uranyl acetate for 25 minutes. After dehydration in ethanol, the tissues were embedded in SPURR plastic and the thin sections were stained with lead citrate.

Virus isolation from all specimens, including the brain biopsy, was attempted in primary human amnion, WI-38, and African Green Monkey tissue cultures. All serological tests were done by the microtitre complement fixation method using two units of complement and two units of antigen. Immunofluorescence for Herpes virus hominis on the brain specimen was also attempted.

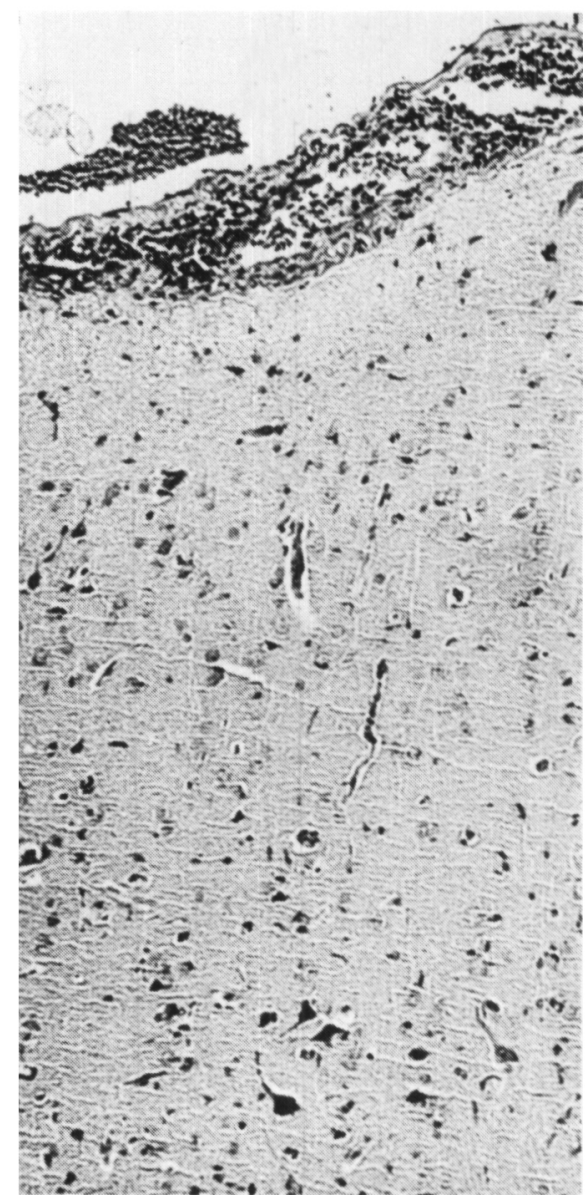

Figure 1: Brain biopsy from patient No. 1 displaying lymphocytic infiltration of the leptomeninges ( $H \& E, X 250$ ). 
TABLE I

Viral Antibody Titres, Patient No. 1 (M.A.)

\begin{tabular}{|c|c|c|c|c|}
\hline \multirow[t]{2}{*}{ Virus } & \multicolumn{4}{|c|}{$\begin{array}{l}\text { Reciprocal of Complement } \\
\text { Fixation Titre }\end{array}$} \\
\hline & 19/9/72 & $24 / 10 / 72$ & & $15 / 1 / 73$ \\
\hline Herpes virus hominis & 32 & 8 & 8 & \\
\hline Rubeola (CSF) & 88 & & & \\
\hline Rubeola & 8 & 16 & 16 & 16 \\
\hline Mumps & 8 & 8 & $<8$ & \\
\hline Western Equine Encephalitis & 8 & 8 & 8 & \\
\hline St. Louis Encephalitis & $<8$ & $<8$ & $<8$ & \\
\hline California Encephalitis & 88 & 8 & 8 & \\
\hline Mycoplasma pneumoniae & 8 & 8 & 16 & \\
\hline Parainfluenza I & 16 & 8 & $<8$ & \\
\hline Parainfluenza II & 16 & 8 & $<8$ & \\
\hline Parainfluenza III & 16 & 8 & 8 & \\
\hline
\end{tabular}

TABLE II

Viral Antibody Titres, Patient No. 2 (C.W.)

Reciprocal of Complement Fixation Titre

\begin{tabular}{|l|c|c|}
\hline & \multicolumn{2}{|c|}{ Pixation } \\
\hline Herpes virus hominis & 8 & $8 / 3 / 73$ \\
\hline Rubeola & 8 & 4 \\
\hline Mumps & 32 & 32 \\
\hline Western Equine Encephalitis & $<4$ & $<4$ \\
\hline Mycoplasma pneumoniae & $<8$ & $<8$ \\
\hline Parainfluenza I & $<8$ & $<8$ \\
\hline Parainfluenza II & $<8$ & $<8$ \\
\hline Parainfluenza III & $<8$ & $<8$ \\
\hline
\end{tabular}

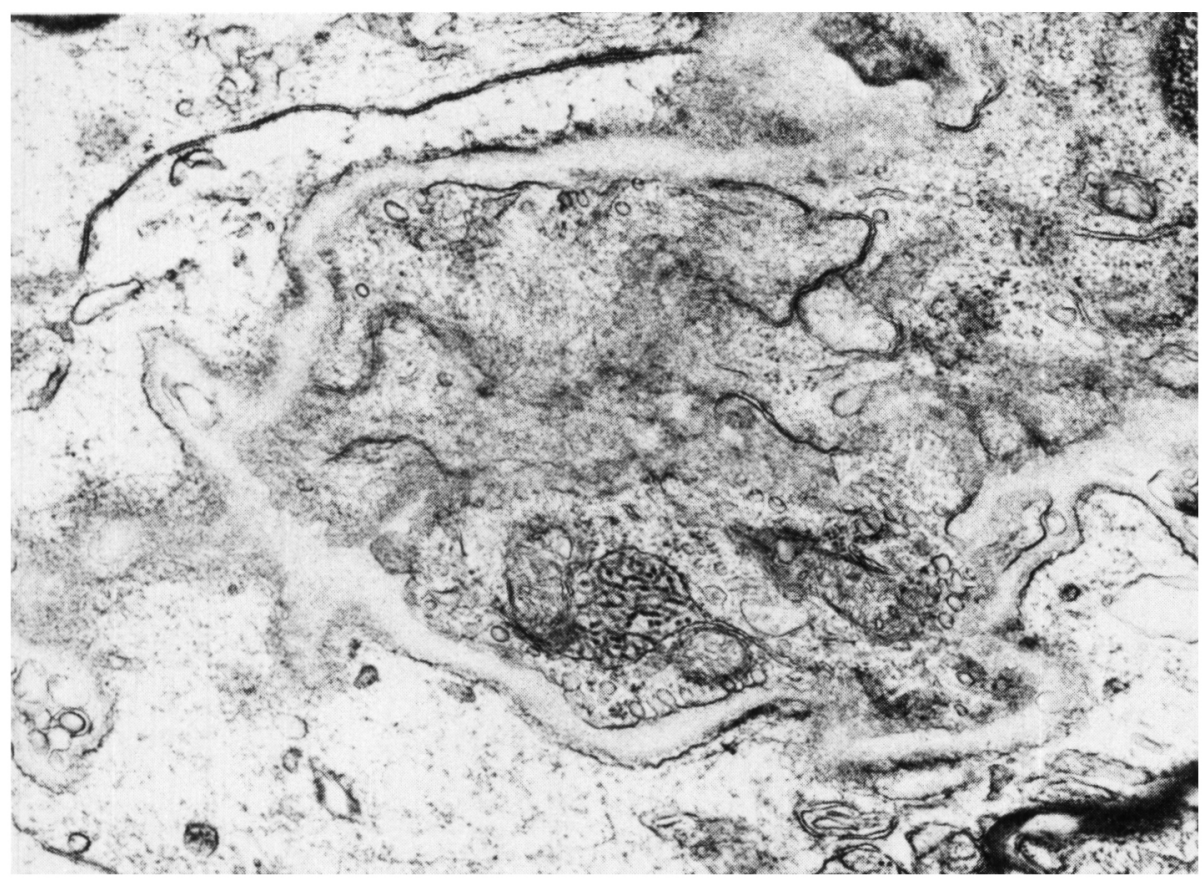

Figure 2: A capillary with paramyxovirus-like aggregates in its endothelial lining (X 24.100).

\section{RESULTS}

Viral Studies

The serological studies are summarized in Tables I and II. There were no significant serological titre rises except for the four-fold rise in the complement fixation (CF) titre to mycoplasma in patient No. 1 (M.A.). She also had a four-fold fall in the CF titre to Herpes virus hominis, and in the Parainfluenza I and II titres. Viral cultures of her pharynx, urine, stool, brain biopsy and CSF were negative. Immunofluorescence for Herpes virus hominis antigen in the brain biopsy was negative.

In patient No. 2 (C.W.), viral cultures of stool, tracheal secretion, and brain biopsy were all negative.

\section{Light Microscopy}

In patient No. 1 (M.A.), small numbers of mononuclear cells were present in the leptomeninges with focal accentuations around venules (fig. 1). Perivascular collections of lymphocytes and occasional histiocytes were seen predominatnly in the cortex. Mild microglial proliferation with early attempts to form 'glial nodules' was more pronounced at the junction of cortex with the white matter. The cortical cytoarchitecture was preserved, but a few neurons were shrunken and displayed nuclear and cytoplasmic hyperchromasia. Early astrocytic proliferation was seen in the deeper layers of the cortex and around the perivascular spaces. No intranuclear or intracytoplasmic inclusions were present. A narrow strip of subcortical white matter was unsatisfactory for proper histological evaluation.

In patient No. 2 (C.W.), the brain biopsy showed minimal satellitosis, but there were no perivascular or leptomeningeal inflammatory infiltrates nor was there a significant proliferation of microglia.

\section{Electron Microscopy}

No intranuclear or intracytoplasmic viral nucleocapsid was found in either patient. However, intertwining tubular arrays were present in hematogenous mononuclear cells and neuronal cell elements. Only occasionally were they seen in the en- 


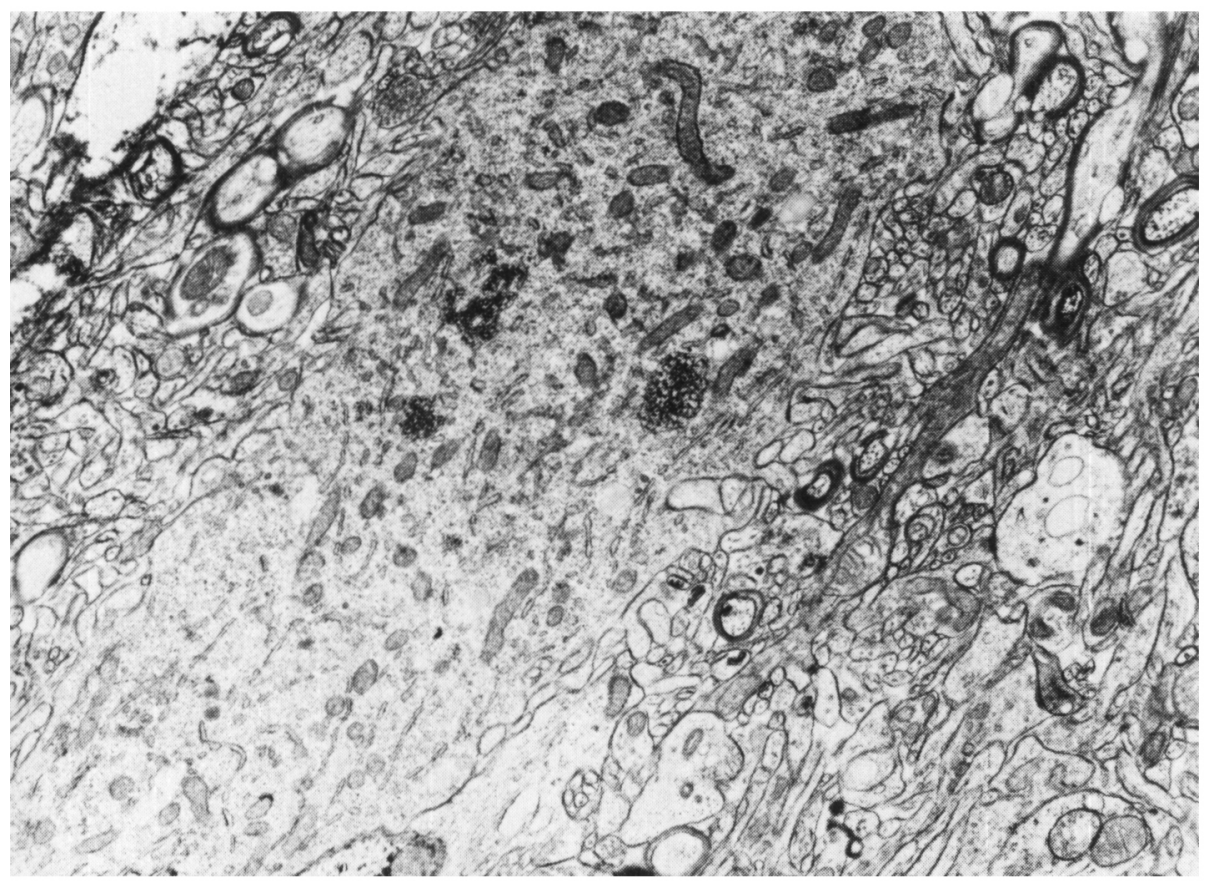

Figure 3: A profile, possibly an oligodendroglion or microglion, with more than one aggregate (X 12.450).

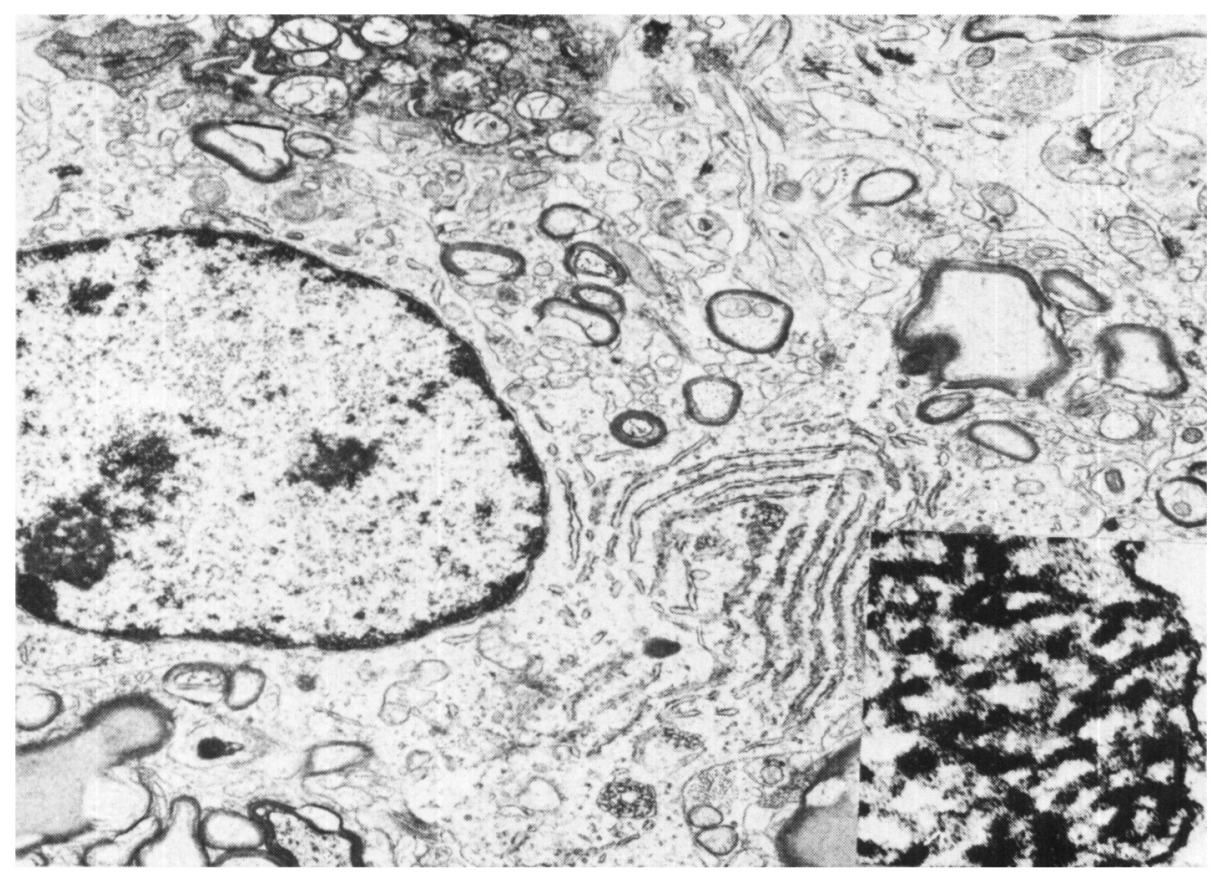

Figure 4: The aggregates are closely related to the rough endoplasmic reticulum (X 18.500). Insert shows a trilaminar unit membrane derived from the rough $E . R$. surrounding the aggregate (X 127.800).

dothelium of capillaries. The individual tubules measured approximately $24 \mathrm{~nm}$. in outside diameter. When present in endothelial cells, they were tightly packed and homogenously electron dense (fig. 2). When seen in the perikarya of other cells they were loosely arranged and their tubular nature was more apparent as their central electronlucent core was clearly outlined in some planes of section. It was difficult to decide whether the neuronal cell elements were nerve cells or as- troglia since fixation of the tissue was not too satisfactory. However, some of the profiles in which these aggregates were present were definitely glial in origin. Others seemed to belong to satellite oligodendroglia or to microglia (fig. 3). In the perikarya, the tubular aggregates were often related to the rough endoplasmic reticulum (ER) (fig. 4). At higher magnification, a trilaminar unit membrane structure, possibly derived from rough $E R$, was seen to partially surround or to be continous with these arrays (fig 4. insert). Occasionally their continuity with the nuclear membrane was clearly outlined (fig. 5).

Inside the glial and neuronal nuclei of both patients, skeins of filamentous material were seen. These were usually arranged in whorls with a granular electron dense material often entrapped within the filamentous coils (fig. 6). A clear halo sometimes intervened between these bodies and the rest of the nuclear material. They ranged in size from $0.3 \mu$ to $1.2 \mu$. Occasionally more than one of these bodies (up to four) were seen in each nucleus (fig. 7). Rarely were these bodies encountered in longitudinal sections and in these instances their intimate relations with the nuclear envelope was striking (fig. 8). Many endothelial cells were swollen and a few lymphocytes, along with phagocytes, were seen in the perivascular zones in patient No. 1 (M.A.). Several "dark" cells (Cohen and Pappas, 1969) were present in both patients.

\section{DISCUSSION}

In patient No. 1 (M.A.), the history, clinical course and brain biopsy were compatible with the diagnosis of viral encephalitis, although a causative virus was neither isolated or identified by serologic tests. She had a low but significant serological rise to mycoplasma pneumoniae. This agent has been incriminated in encephalitis, however, this association is based only on a few case reports and is still tenuous (Hodges et al, 1972). The four-fold drop in titre to Herpes virus hominis is sometimes thought to represent a late serologic 


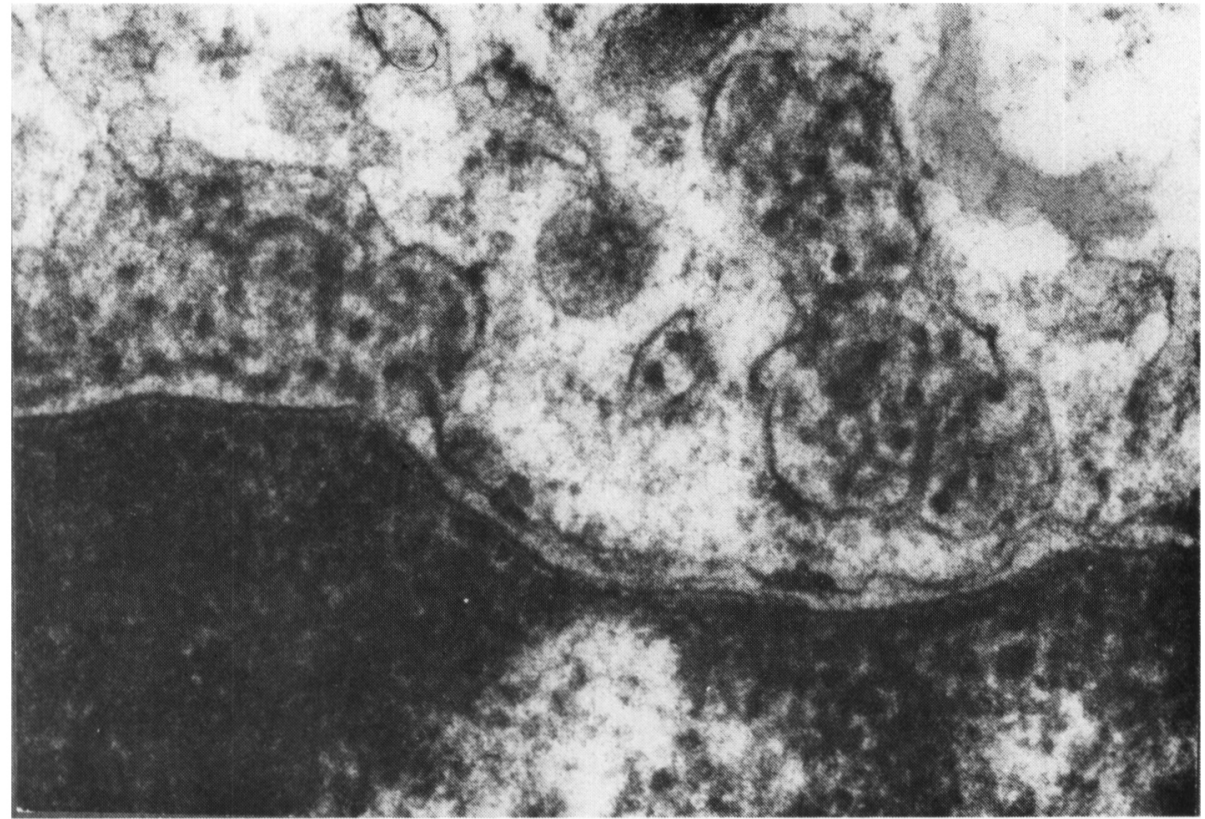

Figure 5: The continuity of the tubular arrays with the nuclear membrane is illustrated (X 88.540).
In both patients, the pertinent ultrastructural finding was the presence of cytoplasmic paramyxoviruslike aggregates and whorled filamentous nuclear bodies. These two structures were rarely seen together in the same cell (fig. 9). The paramyxovirus-like aggregates were similar to the virus-like particles first observed by Gyorkey et al (1969) in the glomerular endothelial cells of lupus nephritis. Similar profiles were later described in different tissues under a variety of conditions (Murphy et al, 1968; Anzil and Blinzinger, 1972; Blinzinger et al, 1969; and Landry and Winkelmann, 1972). In the human CNS, they have been most commonly described in association with viral encephalitides. Baringer (1971) noted their presence in a cerebral biopsy from a patient with herpes encephalitis as well as in

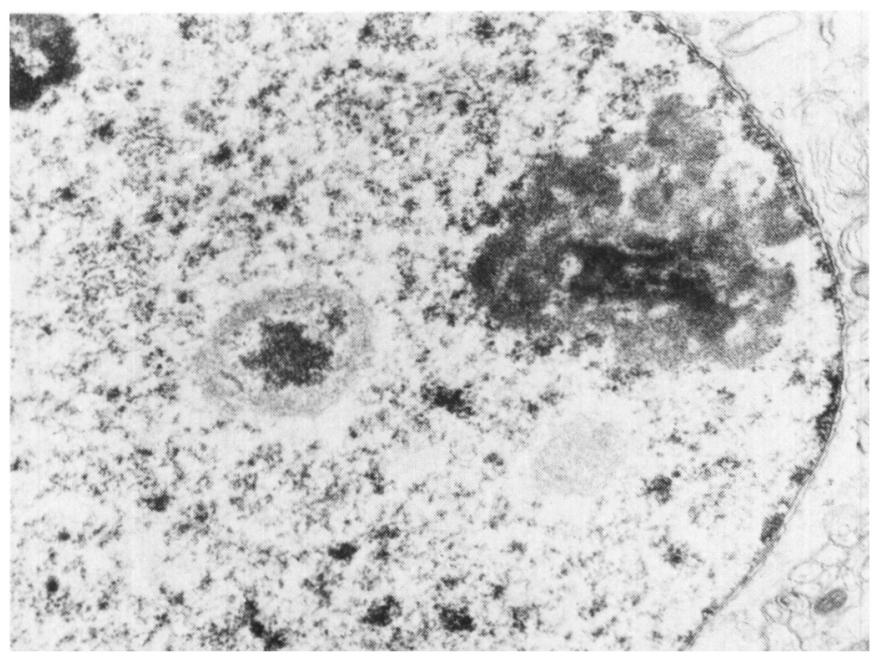

Figure 6: Two nuclear filamentous bodies: a clear halo surrounds one of them and the other shows entrapped electron dense material (X 23.100).

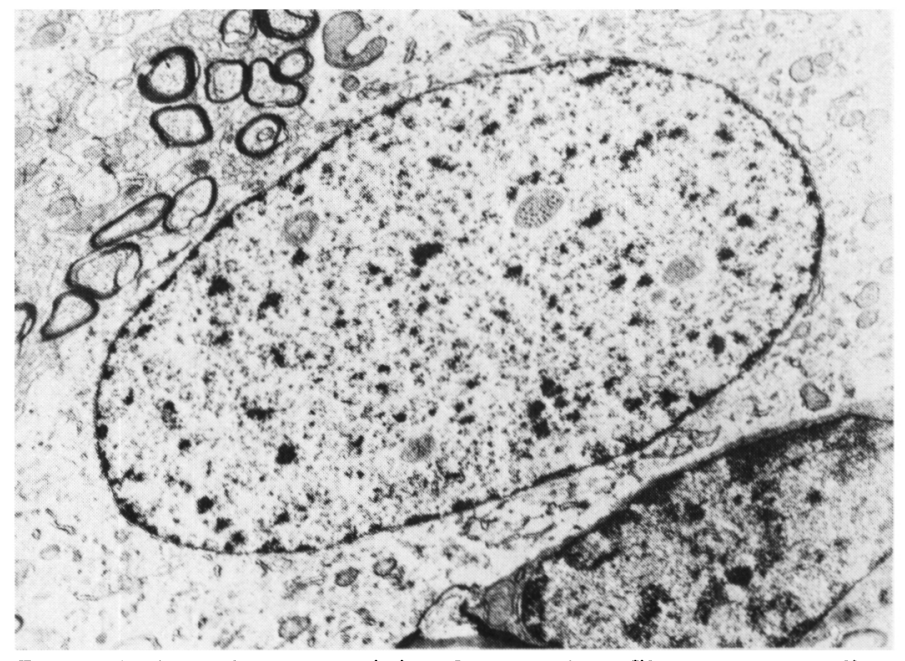

Figure 7: A nucleus containing four nuclear filamentous bodies (X 13.620). change in the course of Herpes encephalitis. However, the first serological specimens were obtained within four days of the onset of illness, so it is unlikely that we can ascribe any significance to this small drop in titre. Although SSPE was considered, despite an atypical clinical presentation, the low CSF and serum titres for rubeola make this diagnosis unlikely.

In patient No. 2(C.W.), the history and the clinical findings suggested an encephalitis, but the brain biopsy failed to display an inflammatory response and viral cultures, as well as the serologic tests, were negative. However, these negative findings did not totally preclude the clinical impression of encephalitis as the small amount of tissue obtained at biopsy may not have been representative. Also a large proportion of presumed viral encephalitis in North America lack specific viral diagnosis (Center for Disease Control - "Annual Encephalitis Summary - 1970", 1972). experimental herpes simplex encephalitis of rabbits and their absence in the control animal (Baringer and Griffith, 1970). However, they were also seen in non-viral conditions such as Krabbe's disease (Haas and Yunis, 1970). In all these reports, the aggregates were almost exclusively present within endothelial cells and less frequently in mononuclear cells. Rarely were they reported in perikarya of neuronal cell elements (Uzman et al, 1971). In the present study, on the contrary, the aggregates 


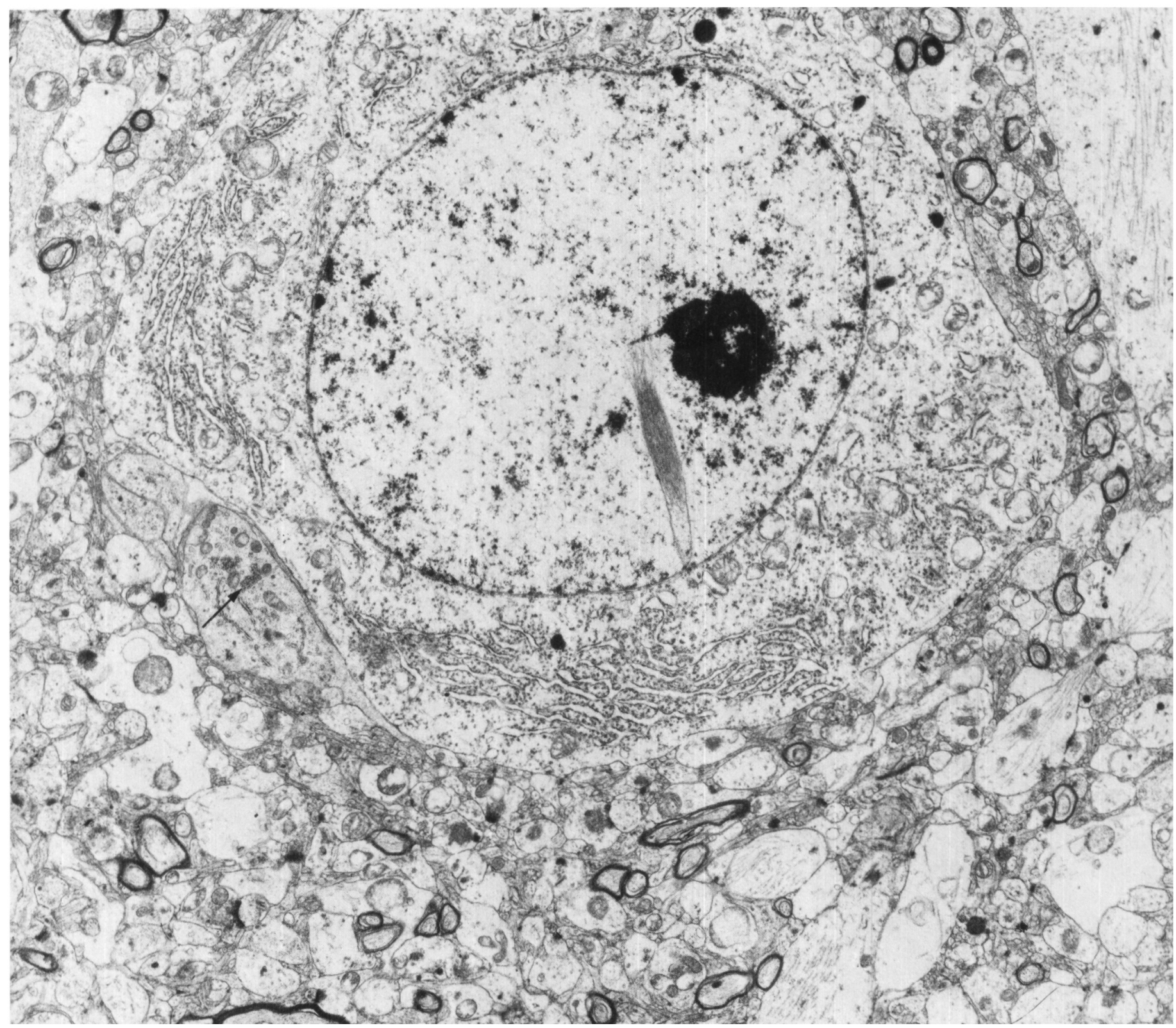

Figure 8: A longitudinal section of a filamentous nuclear body of a neuron. Its intimate relation to the nuclear envelope is apparent.

The arrow points to a profile, possibly a satellite oligodendroglion, which contains the paramyxovirus-like aggregates (X 26.400 ).

were mostly seen in mononuclear cells and in cells of the nervous system. They were conspicuously rare in endothelial cells. Their significance in viral diseases or other conditions in which a viral etiology is suspected has not been settled. They do not represent viral nucleocapsids, but are considered most likely to be a peculiar response on the part of the endoplasmic reticulum to a poorly understood stimulus. These aggregates have been described in normal human leucocytes, but only in invitro studies (Chandra, 1968).
Similarly, the whorled filamentous nuclear bodies have been reported in several pathological conditions (Tommasi et al, 1970, and Masurovsky et al, 1967) as well as in normal tissues (Peters et al, 1970). In the CNS, they have been observed in neoplastic conditions including meningioma (Robertson, 1964) and glioblastoma (Robertson and MacLean, 1965), storage diseases, such as metachromatic leukodystrophy (Perier and Vanderhaeghen, 1966) and in a case of myoclonic epilepsy (Brown et al, 1968). They are the most frequently encountered abnormality reported in SSPE ( $\mathrm{Zu}$ Rhein and Chou, 1968); and a possible relationship to the tubular nucleocapsids of measles virus has been postulated (Herndon and Rubinstein, 1968; Oyanagi et al, 1970). However, Zu Rhein and Chou (1968) have expressed some reservations. Moreover, these bodies seem to be more common in non-pathological tissues than was generally appreciated in the past (Dupuy-Coin and Bouteille, 1972). Recently, Feldman and Peters (1972) have noted an increase in their fre- 


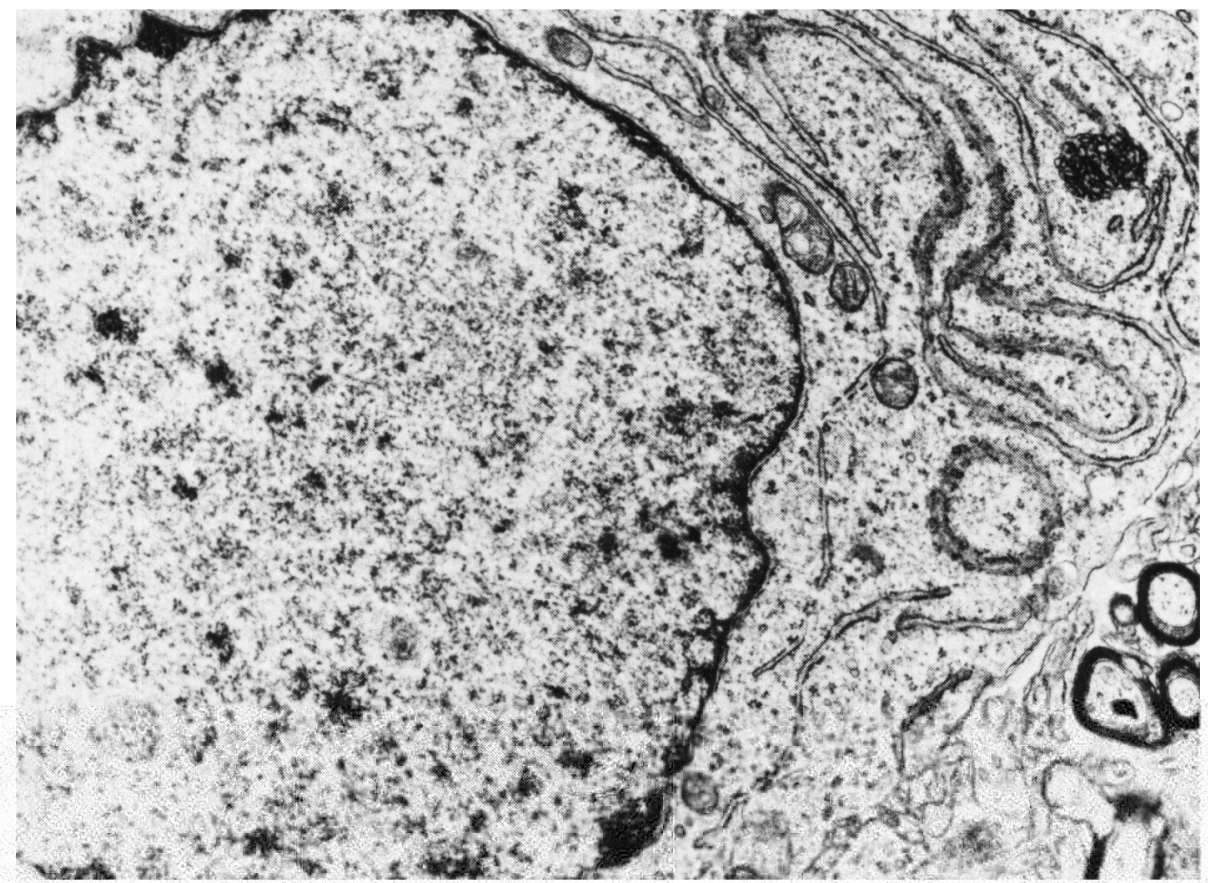

Figure 9: A hematogenous mononuclear cell containing both cytoplasmic aggregates and nuclear filamentous bodies (X 19.550).

quency in normal ageing rats and associated them with heightened cellular activity.

In the cases we presented these nuclear bodies were abundant despite the fact that SSPE was disproven serologically, viral nucleocapsids were not seen and, in case No. 2, the diagnosis of viral encephalitis was presumptive. The mere superimposition of a viral nucleocapsid on such frequently occuring nuclear bodies does not necessarily imply that the fibrillar material of the nuclear bodies are converted or synthesized into nucleocapsids as has been suggested by Hadfield et al, (1972).

It is therefore apparent from this study and previous other studies that there is no direct proof to indicate that these two structures, namely, the cytoplasmic paramyxovirus-like particles and the nuclear filamentous bodies, are viral nucleocapsids or a stage thereof.

\section{ACKNOWLEDGEMENTS}

Part of this work is supported by grant No. MA-4958 from the Medical Research Council of Canada.

We are indebted to Dr. F. S. Dominique from the Department of Neurology at St. Boniface Hospital for referring the second patient, to Mr. W. Stackiw from the Provincial Laboratories for his laboratory assistance and Dr. G. Hogg for reviewing the manuscript.

\section{REFERENCES}

ANZIL, A. P. and BLINZINGER, K. (1972) Electron microscopic studies of rabbit central and peripheral nervous system in experimental Borna disease. Acta Neuropathologica (Berl.) 22, 305-18.

BARINGER, J. R. (1971) Tubular aggregates in endoplasmic reticulum in herpes simplex encephalitis. New England Journal of Medicine 285, 943-5.

BARINGER, J. R. and GRIFFITH, J. F. (1970) Experimental herpes simplex encephalitis: early neuropathologic changes. Journal of Neuropathology and Experimental Neurology 29, 89-104.

BARINGER, J. R. and SWOVELAND, P. (1972) Tubular aggregates in endoplasmic reticulum. Evidence against their viral nature. Journal of Ultrastructural Research 41, 270-6.

BLINZINGER, K., SIMON J., MAGRATH, D. and BOULGER, L. (1969) Poliovirus crystals within the endoplasmic reticulum of endothelial and mononuclear cells in the monkey spinal cord. Science 163, 1336-7.

BROWN, J. W., KOTORII, K. and RIEHL, J. L. (1968) Ultrastructural studies in myoclonus epilepsy (Clinical UnverrichtLafora's disease). Neurology 18, 427-38.

CENTER FOR DISEASE CONTROL “Annual Encephalitis Summary - 1970", Jan.
1972. DHEW Publication No. (HSM) 72 8093.

CHANDRA, S. (1968) Undulating tubules associated with endoplasmic reticulum in pathologic tissues. Laboratory Investigation $18,422-8$.

COHEN, E. B. and PAPPAS, G. D. (1969) Dark profiles in the apparently normal central nervous system: a problem in the electron microscopic identification of early anterograde axonal degeneration. Journal of Comparative Neurology 136, 375-96.

DUPUY-COIN, A. M. and BOUTEILLE, $M$. (1972) Developmental pathway of granular and beaded nuclear bodies from nucleoli. Journal of Ultrastructural Research 40, 55-67.

FELDMAN, M. L. and PETERS, A. (1972) Intranuclear rods and sheets in rat cochlear nucleus. Journal of Neurocytology 1, 109-27.

GYORKEY, F., MIN, K. W., SINKOVICS, J. G. and GYORKEY, P. (1969) Systemic lupus erythematous and myxovirus. New England Journa! of Medicine 280, 333.

HAAS, J. E. and YUNIS, E. J. (1970) Tubular inclusions of systemic lupus erythematosus. Ultrastructural observations regarding their possible viral nature. Experimental and Molecular Pathology 12, 257-63.

HADFIELD, M. G., DAVID, R. B. and ROSENBLUM, W. I. (1972) Coiled nucleocapsid configuration in subacute sclerosing panencephalitis (SSPE). Acta Neuropathologica (Berl.) 21, 263-71.

HERNDON, R. M. and RUBINSTEIN, L. J. (1968) Light and electron microscopy observations on the development of viral particles in the inclusions of Dawson's encephalitis (subacute sclerosing panencephalitis). Neurology 18, Part 2, 8-20.

HODGES, G. R., FASS, R. I. and SASLAW, S. (1972) Central nervous system disease associated with mycoplasma pneumoniae infections. Archives of Internal Medicine 130, 277-82.

LANDRY, M. and WINKELMANN, R. K. (1972) Tubular cytoplasmic inclusion in dermatomyositis. Mayo Clinic Proceedings 47, 479-92.

MASUROVSKY, E. B., BUNGE, M. B. and BUNGE, R. P. (1967) Cytological studies of organotypic cultures of rat dorsal root ganglia following $X$-irradiation in-vitro, I. Changes in neurons and satellite cells. Journal of Cell Biology 32, 467-96.

MURPHY, F. A., HARRISON, A. K., GARY, G. W. Jr., WHITFIELD, S. G. and FORRESTER, F. T. (1968) St. Louis encephalitis virus infection of mice: electron microscopic studies of central nervous system. Laboratory Investigation 19 , 652-62.

OYANAGI, S., MÜlLER, D., TER MEULEN, V., KATZ, M. and KOPROWSKI, H. (1970) Electron microscopic observations in subacute sclerosing pan- 
encephalitis brain cell cultures; their correlation with cytochemical and immunocytologic findings. Journal of Virology 6 , $370-9$.

PERIER, $O$. and VANDERHAEGHEN, J. J. (1966) Indications étiologiques apportées par la microscopie electronique dans certaines encephalites humaines. Revue Neurologique 115, 250-4.

PETERS, A., PALAY, S. L. and WEBSTER, H. (1970) The fine structure of the nervous system. New York: Harper and Row, 42-3.
ROBERTSON, D. M. and MACLEAN, J. D. (1965) Nuclear inclusions in malignant gliomas. Archives of Neurology 13: 287-96.

ROBERTSON, D. M. (1964) Electron microscope studies of nuclear inclusions in meningiomas. American Journal of Pathology 45, 835-48.

TOMMASI, M., BERARD-BADIER, M., : TOGA, M., and VEDRENNE, C. (1970)
Maladies virales du système nerveu. Annales d'Anatomie Pathologique 15, 129-52.

UZMAN, B. G., SAITO, H. and KASAC, M. (1971) Tubular arrays in the endoplasmic reticulum in human tumor cells. Laboratory Investigation $24,492-8$.

ZU RHEIN, G. M. and CHOU, S. M. (1968) Subacute sclerosing panencephalitis. UItrastructural study of a brain biopsy. Neurology 18, Part 2, 146-60. 